\title{
THE EFFECT OF A FORMULATION BASED ON MADURAMYCIN AND NICARBAZINE ON RATS AND BROILER CHICKENS IN A SUBACUTE EXPERIMENT
}

\author{
Roman Dotsenko, Maryna Romanko, Yevheniia Vashchyk, Andriy Zakhariev, \\ Andrii Zemlianskyi, Ekaterina Dotsenko, Nataliia Seliukova
}

The aim: to determine the effect of a preparative form of an antiemeric agent based on maduramycin and nicarbazine on the body of white rats and broiler chickens under the conditions of a subacute experiment.

Materials and methods. The formulation based on maduramycin and nicarbazine was administered to rats and broiler chickens with feed for 28 days. One control and three experimental groups were formed for the experiment: Group I animals received a complete diet without admixture of the formulation (control group), Group II - animals that were administered the formulation (by the amount of active substances) at a dose of $5.0 \mathrm{mg} / \mathrm{kg}$, III - $25.0 \mathrm{mg} / \mathrm{kg}$ and IV $50.0 \mathrm{mg} / \mathrm{kg}$ of feed, respectively. In order to establish the toxic effect of the formulation on the body of experimental birds on 7, 14, 28 days of the experiment and 7 days after discontinuation of the formulation, 5 heads from each group were killed under light ether anesthesia, blood samples were taken for hematological and biochemical studies.

Results. During the study of the general clinical condition of rats and broiler chickens of the experimental groups, no significant changes in behavior and appearance were detected, compared with the control.

Hematological parameters of broiler chickens it was found that the receipt of the formulation with feed at doses of 5,25 and $50 \mathrm{mg} / \mathrm{kg}$ body weight, causes a decrease in hemoglobin and an increase in hematocrit in broiler chickens on day 7 of the experiment. It was found that the changes are reversible, on the 28th day of the experiment the value of these indicators was within the physiological norm.

In the study of hematological and biochemical parameters of rats, it was found that the receipt of the formulation with food in doses of 25.0 and $50.0 \mathrm{mg} / \mathrm{kg}$ for 28 days, causes a decrease in hemoglobin and increase hematocrit, total protein, albumin, creatinine and urea in male rats on the 7 th day of the experiment.

Conclusions. Under conditions of repeated oral administration of the preparation mixture to rats and poultry at doses of 5,25 and $50 \mathrm{mg} / \mathrm{kg}$ body weight in the absence of clinical signs of poisoning, insignificant fluctuations in hematological and biochemical parameters were identified

Keywords: toxicity, rats, broiler chickens, maduramycin, nicarbazine, eimeriosis

\section{How to cite:}

Dotsenko, R., Romanko, M., Vashchyk, Y., Zakhariev, A., Zemlianskyi, A., Dotsenko, E., Seliukova, N. (2021). The effect of a formulation based on maduramycin and nicarbazine on rats and broiler chickens in a subacute experiment. ScienceRise: Biological Science, 3 (28), 41-48. doi: http://doi.org/10.15587/2519-8025.2021.241245

(C) The Author(s) 2021

This is an open access article under the Creative Commons CC BY license hydrate

\section{Introduction}

Coccidiosis is one of the most common poultry diseases in the world. This is due to the fact that pathogens penetrate the intestinal epithelium, causing enteritis and diarrhea. The bird is unable to assimilate feed nutrients, which leads to low growth rates, increased feed conversion, and eventually death of the bird [1].

With outbreaks of coccidiosis in poultry farms, average daily gains decrease by $5-10 \%$, feed conversion increases by $7-12 \%$, mortality can reach $25-40 \%$. Often the disease occurs in the form when the bird is clinically healthy, however, gains decrease and the ratio of the amount of feed consumed per unit of live weight gain increases. The recovery of growth rates, even after treatment, is very slow. Some batches of broilers may not be able to reach their full production potential. Coccidia can also negatively affect the immune system, making the bird more vulnerable to other pathogens. In general, eimeriosis is considered one of the most severe diseases for poultry health, which causes huge economic losses for poultry producers around the world [2].

To combat eimeriosis, chemopreventive agents are used that inhibit or completely stop the formation of endogenous forms of coccidia in the bird's body. These anti-coccidial drugs include ionophore coccidiostatics. These are substances that contain a polyester group. These include such coccidiostatics: sodium monensin, sodium lasalocid, ammonium maduramycin, narazine, sodium salinomycin, sodium semduramycin. Ionophore antibiotics have a coccidiostatic effect against extracellular asexual forms (sporozoites, merozoites) of the endogenous development of eimeria in poultry [3]. Their anti- 
coccidic action is based on the ability to form complexes with monovalent ions of basic metals (potassium and sodium), which makes cell membranes permeable to these ions in the internal and opposite directions, thus changing the concentration of these ions in eimeria cells. To maintain the osmotic balance, the parasite is forced to expend a lot of energy, which, as a result, leads to the overflow of the cell with water and its death. Since the mechanism of action of ionophore antibiotics is practically the same, cross-resistance often develops in coccidia to these substances [4].

Ionophores, despite their rather high anti-coccidial efficacy, maintain the cycle of some eimeria, and thus contribute to the development of immunity. This property, combined with a wide spectrum of action, including on pathogenic bacteria that negatively affect the growth and conversion of feed, makes these drugs the main in the fight against coccidiosis in broilers and replacement chickens [5].

Another group of anti-eimer drugs includes chemically synthesized drugs: decoquinate, robenidine hydrochloride, clopidol, toltrazuril, diclazuril, amprolium and its derivatives zoalene and nicarbazine, diaveridin. Chemicals are effective against all types of eimeria, but their disadvantage is that the resistance of parasites to their action develops faster than to ionophores. Therefore, an uncontrolled increase in doses should be avoided when using chemical coccidiostatics, because this can lead to the occurrence of epizootics. The use of combined drugs slows down the adaptation of coccidia to drugs and has a positive effect in the control of coccidiosis [6].

With the evocation of the authorities of the new combined types, it is necessary to give respect not only to the combined therapeutic effect, but to the toxic injection of the drug. It is necessary to respect the animals, not only for the GOST, the toxicity of ale, and at the forefront of toxic effects, which can be manifested with trivial appropriate treatment of the drug at the doses of the lowest for toxic [7-8]. In the case of fallowness from the speed of action and doses, the signs of detachment can be seen in the steps of degradation of the homeless camp, or at once manifested in important forms. The creatures grow awake, showing sensitivity to the occasional irritant, and the incols grow aggressive. For an intensive relocation, the repression of the creatures is very buzzing, with signs of a loss of control and coordination of rucks. In some cases, they observed one by one cloned convulsions, animals move their limbs unnaturally [9].

In case of poisoning with low toxic substances, animals first show anxiety, then muscle cramps begin, turning into a tremor, which spreads throughout the body and intensifies. Against the background of a tremor, shortness of breath may appear, which worsens over time. For convulsive attacks of the creature, go to the stage of depression. Before the hour, the middle step is cut off, the tremor is not very bright, but it is not very bright. Reflexes are malnourished, sometimes are more likely to show up in appetite or, vice versa, and not to liven up the feed [10].

According to our preliminary data, acute toxicity of the formulation by oral administration shown that the LD50 of the preparative form of antiemeric agent for white mice for a single oral administration is $238.05 \pm 28.08 \mathrm{mg} / \mathrm{kg}$ body weight. LD50 of the preparative form of antiemeric agent for white rats with a single oral administration is $260.51 \pm 28.83 \mathrm{mg} / \mathrm{kg}$ body weight. LD50 of the preparative form of antiemeric agent for guinea pigs for a single oral administration is $275 \pm 21.12 \mathrm{mg} / \mathrm{kg}$ body weight [11].

The aim: to determine the effect of a preparative form of an antiemeric agent based on maduramycin and nicarbazine on the body of white rats and broiler chickens under the conditions of a subacute experiment.

\section{Materials and methods}

Determination of subacute toxicity of the preparative form of antiemeric agent based on maduramycin and nicarbazine was performed on two species of animals: white male rats and broiler chickens.

Determination of subacute toxicity was carried out in accordance with Test No. 407: Repeated Dose 28day Oral Toxicity Study in Rodents [12]. The studies were carried out on the basis of the vivarium of the toxicological monitoring laboratory NSC «IECVM» in 2016-2017.

In the first stage, the subacute toxicity of the formulation was studied in 80 laboratory adult male rats weighing $200 \pm 20 \mathrm{~g}$. The formulation based on maduramycin and nicarbazine was administered with food for 28 days. For the experiment was formed one control and three experimental groups of 20 rats each: Group I - animals received a complete diet without admixture of the formulation (control group), group II - animals that were administered the formulation (by the amount of active substances) at a dose of $5.0 \mathrm{mg} / \mathrm{kg}$, III $-25.0 \mathrm{mg} / \mathrm{kg}$ and IV $-50.0 \mathrm{mg} / \mathrm{kg}$ of feed, respectively.

Blood sampling for hematological and biochemical studies was performed on days 7, 14 and 28 of the experiment and 7 days after discontinuation of the formulation.

In the dynamics of subacute experiment (daily) in rats studied integrated indicators of animal behavior, appearance, reactions to external stimuli, body weight, water and food intake, as well as indicators that characterize the functions of organs and systems, using generally accepted methods.

In the second stage, subacute toxicity of a formulation based on maduramycin and nicarbazine was studied in broiler chickens. For the experiment on the principle of analogues were formed three experimental and one control group, 20 birds in each $(n=20)$. Prior to the experiment, the bird was weighed and labeled. The chickens of the control and experimental groups were fed good-quality complete feed, which corresponded to age and productivity, in accordance with the approved technological norms.

The formulation was administered orally with food for 28 days. In group I - the bird received a complete diet without the addition of the formulation (control group), group II - the bird, which was administered the formulation at a dose of $5.0 \mathrm{mg} / \mathrm{kg}$, III $-25.0 \mathrm{mg} / \mathrm{kg}$ and IV $-50.0 \mathrm{mg} / \mathrm{kg}$ of feed, respectively.

During the experiment, the clinical condition and behavior of the bird were observed. In the dynamics of subacute experiment (daily) in broiler chickens studied 
integrated indicators (behavior, appearance, reactions to external stimuli, body weight, water and food intake), as well as indicators that characterize the functions of organs and systems, using generally accepted methods .

In order to establish the toxic effect of the formulation on the body of experimental birds on 7, 14, 28 days of the experiment and 7 days after discontinuation of the formulation, 5 chickens from each group were killed under light ether anesthesia, blood samples were taken for hematological and biochemical studies.

Hematological studies included determination of total hemoglobin (HGB), hematocrit (HCT), mean erythrocyte volume (MCV), and erythrocyte count (RBC). Hematological parameters of experimental animals were determined in whole blood with anticoagulant on a hematology analyzer "Sysmex" (Japan) [13].

Studies of the functional status of the liver and kidneys included determination of total protein, albumin, creatinine, urea (rats), uric acid (broiler chickens). The level of activity of the following enzymes was determined in blood serum: alanine aminotransferase and aspartate aminotransferase [13]. For biochemical studies, blood serum was obtained by standing in tubes in a thermostat for 15 minutes. To separate the serum from the clot on the inner wall of the tube was performed with a stainless steel rod. Centrifuged at $3000 \mathrm{rpm}$ for 15 minutes. Blood serum was collected using a dosing pipette into sterile Eppendorf-type tubes.

Statistical processing of research results was performed using statistical methods (StatPlus v5 for Windows) with determination of the arithmetic mean (M), the statistical error of the arithmetic mean $(\mathrm{m})$, the probability of the difference $(\mathrm{P})$ between the arithmetic means of the two variation series by the confidence factor for the difference of the means $(t)$. The difference between the two values was considered probable at $* \mathrm{p} \leq 0.05$; $* * \mathrm{p} \leq 0.01 ; * * * \mathrm{p} \leq 0.001$ [14].

Experiments conducted on animals do not contradict the current legislation of Ukraine (Article 26 of the Law of Ukraine 5456-VI of 16.10.2012 "On protection of animals from cruel treatment") and "General ethical principles of animal experiments", adopted by the First National Congress of Bioethics (Kyiv, 2001), international bioethical standards (materials of the IV European Convention for the Protection of Vertebrate Animals Used for Experimental and Other Purposes) (Strasbourg, 1985) and Council Directive 86/609/EEC of 24 November 1986 on the approximation of laws, regulations and administrative provisions of the Member States regarding the protection of animals used for experimental and other scientific purposes [15]. Animal studies were conducted taking into account the basic principles of bioethics (conclusion approved by the Commission on Bioethical Examination of National scientific center «Institute of Experimental and Clinical Veterinary Medicine» dated 05.02.2010).

\section{Research results}

During the study of the general clinical condition of rats of the experimental groups, no significant changes in behavior and appearance were detected, compared with the control. Throughout the observation period, the animals were active, had a satisfactory appetite, responded well to sound and light stimuli, they retained reflex excitability; respiratory, urination and defecation disorders were not noted.

The results of the study of hematological parameters of rats are shown in Table 1.

Table 1

Hematological parameters of blood of male rats with subacute oral administration of a formulation based on maduramycin and nicarbazine $(\mathrm{M} \pm \mathrm{m} ; \mathrm{n}=5)$

\begin{tabular}{|c|c|c|c|c|}
\hline \multirow[b]{2}{*}{ Groups } & \multicolumn{4}{|c|}{ Terms of research, days } \\
\hline & 7 & 14 & 28 & $\begin{array}{c}7 \text { after } \\
\text { administration }\end{array}$ \\
\hline \multicolumn{5}{|c|}{ Total hemoglobin (HGB), $\mathrm{g} / \mathrm{dm}^{3}$} \\
\hline Control & $117.50 \pm 4.50$ & $118.60 \pm 3.10$ & $119.18 \pm 5.40$ & $118.11 \pm 3.20$ \\
\hline $5,0 \mathrm{mg} / \mathrm{kg}$ & $118.01 \pm 3.60$ & $118.87 \pm 2.60$ & $118.30 \pm 4.10$ & $119.75 \pm 2.10$ \\
\hline $25,0 \mathrm{mg} / \mathrm{kg}$ & $112.64 \pm 2.30 *$ & $117.53 \pm 3.80$ & $117.97 \pm 2.56$ & $117.40 \pm 4.50$ \\
\hline $50,0 \mathrm{mg} / \mathrm{kg}$ & $110.30 \pm 3.10^{*}$ & $116.61 \pm 2.30$ & $117.44 \pm 4.10$ & $118.05 \pm 2.65$ \\
\hline \multicolumn{5}{|c|}{ Hematocrit (HCT), \% } \\
\hline Control & $46.31 \pm 1.28$ & $47.18 \pm 2.12$ & $46.08 \pm 0.90$ & $47.11 \pm 2.26$ \\
\hline $5,0 \mathrm{mg} / \mathrm{kg}$ & $45.24 \pm 2.08$ & $46.86 \pm 1.20$ & $45.10 \pm 0.72$ & $45.04 \pm 1.15$ \\
\hline $25,0 \mathrm{mg} / \mathrm{kg}$ & $48.18 \pm 2.22 *$ & $47.98 \pm 0.86$ & $47.95 \pm 1.35$ & $46.93 \pm 2.34$ \\
\hline $50,0 \mathrm{mg} / \mathrm{kg}$ & $49.92 \pm 1.18^{*}$ & $46.96 \pm 1.36$ & $46.02 \pm 2.08$ & $47.90 \pm 2.12$ \\
\hline \multicolumn{5}{|c|}{ Mean erythrocyte volume (MCV), $\mu^{3}$} \\
\hline Control & $120.98 \pm 2.92$ & $122.20 \pm 2.43$ & $122.88 \pm 1.94$ & $119.98 \pm 2.10$ \\
\hline $5,0 \mathrm{mg} / \mathrm{kg}$ & $121.12 \pm 1.52$ & $124.89 \pm 1.36$ & $120.60 \pm 1.93$ & $122.10 \pm 1.19$ \\
\hline $25,0 \mathrm{mg} / \mathrm{kg}$ & $120.94 \pm 1.19$ & $122.05 \pm 2.39$ & $121.12 \pm 2.03$ & $120.04 \pm 1.13$ \\
\hline $50,0 \mathrm{mg} / \mathrm{kg}$ & $122.06 \pm 2.01$ & $120.10 \pm 2.18$ & $121.03 \pm 1.12$ & $120.06 \pm 1.55$ \\
\hline \multicolumn{5}{|c|}{ Erythrocytes (RBC), 1012/dm ${ }^{3}$} \\
\hline Control & $8.54 \pm 0.49$ & $7.86 \pm 0.42$ & $8.21 \pm 0.59$ & $8.05 \pm 0.16$ \\
\hline $5,0 \mathrm{mg} / \mathrm{kg}$ & $8.66 \pm 0.23$ & $8.75 \pm 0.39$ & $8.46 \pm 0.28$ & $8.32 \pm 0.17$ \\
\hline $25,0 \mathrm{mg} / \mathrm{kg}$ & $8.71 \pm 0.25$ & $8.65 \pm 0.84$ & $8.07 \pm 0.56$ & $7.99 \pm 0.21$ \\
\hline $50,0 \mathrm{mg} / \mathrm{kg}$ & $8.93 \pm 0.12$ & $8.23 \pm 0.16$ & $8.56 \pm 0.37$ & $8.54 \pm 0.53$ \\
\hline
\end{tabular}

Notes: $*-p<0.05 ; * *-p<0.01$ according to the indicator in the control 
According to the results of studies, oral administration to male rats of a formulation based on maduramycin and nicarbazine caused changes in some hematological parameters. Thus, on the 7th day of the experiment, a probable decrease in the concentration of total hemoglobin in the blood of rats of groups III and IV (doses of 25.0 and $50.0 \mathrm{mg} / \mathrm{kg}$ ) by 4.14 and $6.13 \%$, re- spectively. An increase in the value of hematocrit on the 7 th day of the experiment in the blood of rats of groups III and IV by 4.03 and $7.79 \%$, respectively. At 14 and 28 days, as well as 7 days after the cessation of the introduction of probable changes in the indicators are not set. The results of the study of the functional status of the liver and kidneys of male rats are shown in Table 2.

Table 2

Dynamics of the main biochemical parameters of serum of male rats with subacute oral administration of a formulation based on maduramycin and nicarbazine $(\mathrm{M} \pm \mathrm{m} ; \mathrm{n}=5)$

\begin{tabular}{|c|c|c|c|c|}
\hline \multirow[b]{2}{*}{ Groups } & \multicolumn{4}{|c|}{ Terms of research, days } \\
\hline & 7 & 14 & 28 & $\begin{array}{c}7 \text { after administra- } \\
\text { tion }\end{array}$ \\
\hline \multicolumn{5}{|c|}{$\mathrm{ALT}, \mu \mathrm{mol} / \mathrm{h} \times \mathrm{cm}^{3}$} \\
\hline Control & $1.32 \pm 0.10$ & $1.35 \pm 0.08$ & $1.38 \pm 0.15$ & $1.38 \pm 0.11$ \\
\hline $5,0 \mathrm{mg} / \mathrm{kg}$ & $1.32 \pm 0.08$ & $1.29 \pm 0.05$ & $1.35 \pm 0.08$ & $1.37 \pm 0.06$ \\
\hline $25,0 \mathrm{mg} / \mathrm{kg}$ & $1.28 \pm 0.12$ & $1.27 \pm 0.12$ & $1.31 \pm 0.10$ & $1.28 \pm 0.12$ \\
\hline $50,0 \mathrm{mg} / \mathrm{kg}$ & $1.31 \pm 0.08$ & $1.28 \pm 0.10$ & $1.29 \pm 0.12$ & $1.30 \pm 0.10$ \\
\hline \multicolumn{5}{|c|}{$\mathrm{AST}, \mu \mathrm{mol} / \mathrm{h} \times \mathrm{cm}^{3}$} \\
\hline Control & $2.21 \pm 0.23$ & $2.22 \pm 0.20$ & $2.30 \pm 0.15$ & $2.27 \pm 0.20$ \\
\hline $5,0 \mathrm{mg} / \mathrm{kg}$ & $2.23 \pm 0.10$ & $2.25 \pm 0.12$ & $2.26 \pm 0.13$ & $2.27 \pm 0.24$ \\
\hline $25,0 \mathrm{mg} / \mathrm{kg}$ & $2.22 \pm 0.21$ & $2.24 \pm 0.16$ & $2.23 \pm 0.18$ & $2.26 \pm 0.14$ \\
\hline $50,0 \mathrm{mg} / \mathrm{kg}$ & $2.17 \pm 0.15$ & $2.19 \pm 0.17$ & $2.20 \pm 0.20$ & $2.25 \pm 0.30$ \\
\hline \multicolumn{5}{|c|}{ Total protein, $\mathrm{g} / \mathrm{dm}^{3}$} \\
\hline Control & $63.20 \pm 2.64$ & $63.20 \pm 2.71$ & $63.10 \pm 2.08$ & $63.50 \pm 3.30$ \\
\hline $5,0 \mathrm{mg} / \mathrm{kg}$ & $64.50 \pm 1.48$ & $64.30 \pm 1.43$ & $64.00 \pm 1.41$ & $64.40 \pm 2.41$ \\
\hline $25,0 \mathrm{mg} / \mathrm{kg}$ & $66.60 \pm 2.03^{*}$ & $64.50 \pm 1.10$ & $64.90 \pm 1.23$ & $63.20 \pm 2.42$ \\
\hline $50,0 \mathrm{mg} / \mathrm{kg}$ & $69.20 \pm 3.16^{*}$ & $65.60 \pm 2.47$ & $63.20 \pm 1.74$ & $62.50 \pm 3.51$ \\
\hline \multicolumn{5}{|c|}{ Albumin, $\mathrm{g} / \mathrm{dm}^{3}$} \\
\hline Control & $41.06 \pm 1.53$ & $42.50 \pm 1.85$ & $43.30 \pm 2.11$ & $42.30 \pm 1.08$ \\
\hline $5,0 \mathrm{mg} / \mathrm{kg}$ & $42.74 \pm 1.34$ & $43.00 \pm 2.10$ & $42.12 \pm 1.37$ & $42.50 \pm 1.32$ \\
\hline $25,0 \mathrm{mg} / \mathrm{kg}$ & $46.05 \pm 1.82 *$ & $41.12 \pm 1.64$ & $42.18 \pm 0.66$ & $41.80 \pm 2.03$ \\
\hline $50,0 \mathrm{mg} / \mathrm{kg}$ & $49.10 \pm 1.20^{*}$ & $40.10 \pm 1.72$ & $41.18 \pm 1.6$ & $42.60 \pm 1.10$ \\
\hline \multicolumn{5}{|c|}{ Creatinine, $\mu \mathrm{mol} / \mathrm{dm}^{3}$} \\
\hline Control & $72.63 \pm 1.72$ & $71.48 \pm 4.10$ & $72.46 \pm 4.61$ & $71.12 \pm 3.60$ \\
\hline $5,0 \mathrm{mg} / \mathrm{kg}$ & $72.42 \pm 2.65$ & $72.95 \pm 1.31$ & $71.85 \pm 4.80$ & $73.31 \pm 4.63$ \\
\hline $25,0 \mathrm{mg} / \mathrm{kg}$ & $76.04 \pm 3.37^{*}$ & $73.01 \pm 2.60$ & $70.05 \pm 6.10$ & $70.58 \pm 6.68$ \\
\hline $50,0 \mathrm{mg} / \mathrm{kg}$ & $78.31 \pm 1.55^{*}$ & $72.32 \pm 4.20$ & $72.09 \pm 7.05$ & $72.17 \pm 8.12$ \\
\hline \multicolumn{5}{|c|}{ Urea, $\mathrm{mmol} / \mathrm{dm}^{3}$} \\
\hline Control & $7.01 \pm 0.17$ & $7.44 \pm 0.41$ & $7.14 \pm 0.88$ & $7.13 \pm 0.36$ \\
\hline $5,0 \mathrm{mg} / \mathrm{kg}$ & $7.55 \pm 0.94$ & $7.48 \pm 0.36$ & $7.25 \pm 0.43$ & $7.46 \pm 0.64$ \\
\hline $25,0 \mathrm{mg} / \mathrm{kg}$ & $8.96 \pm 0.53 *$ & $7.99 \pm 0.43$ & $8.23 \pm 0.26$ & $7.53 \pm 1.10$ \\
\hline $50,0 \mathrm{mg} / \mathrm{kg}$ & $9.16 \pm 0.47 *$ & $8.01 \pm 0.24$ & $7.18 \pm 0.51$ & $7.29 \pm 0.45$ \\
\hline
\end{tabular}

Note: $*-p<0.05 ; * *-p<0.01$ according to the indicator in the control

Assessing the activity of indicator enzymes ALT and AST in the serum of male rats under the influence of a formulation based on maduramycin and nicarbazine, no significant changes were found, the activity values of these enzymes were within the physiological norm at all times of the study. During the study of the functional state of the liver, a probable $(\mathrm{p}<0.05)$ increase in the concentration of total protein in the serum of rats of groups III and IV (doses of 25.0 and $50.0 \mathrm{mg} / \mathrm{kg}$ ) on $7^{\text {th }}$ day of the experiment by 5.38 and $9.49 \%$ respectively. On the 7th day of the experiment recorded a statistically significant increase in the concentration of albumin in the serum of rats III and IV groups by 12.15 and $19.58 \%$, respectively.

In the study of the functional state of the kidneys, a probable increase in the concentration of creatinine and urea on the 7 th day of the experiment in male rats of groups III and IV (doses of 25.0 and $50.0 \mathrm{mg} / \mathrm{kg}$ ) by 4.69 and $7.82 \%$ and 27.82 and $30.67 \%$, respectively. It should be noted that at 14 and 28 days, as well as 7 days after cessation of administration, these indicators were within the physiological norm.

Thus, in the study of hematological and biochemical parameters it was found that the receipt of the formulation based on maduramycin and nicarbazine with food at doses of 25.0 and $50.0 \mathrm{mg} / \mathrm{kg}$ for 28 days, causes a decrease in hemoglobin and increase hematocrit, total protein concentration, albumin, creatinine and urea in male rats on day 7 of the experiment.

During the study of the general clinical condition of broiler chickens of the experimental groups, no significant changes in behavior and appearance were de- 
tected, compared with the control. Throughout the observation period, broiler chickens of the experimental groups were active, had a satisfactory appetite, responded well to sound and light stimuli, and had a characteristic appearance of the breed: comb and earrings were shiny, bright red, yellowish beak, white plumage, close to the surface of the body. Table 3 shows the results of the study of the level of hematological parameters in the blood of broiler chickens at different times of the experiment.

Table 3

The level of hematological parameters of the blood of broiler chickens under the influence of a formulation based on maduramycin and nicarbazine in the dynamics of subacute experiment $(M \pm m, n=5)$

\begin{tabular}{|c|c|c|c|c|}
\hline \multirow[b]{2}{*}{ Groups } & \multicolumn{4}{|c|}{ Terms of research, days } \\
\hline & 7 & 14 & 28 & $\begin{array}{c}7 \text { after } \\
\text { administration }\end{array}$ \\
\hline \multicolumn{5}{|c|}{ Total hemoglobin (HGB), g/dm ${ }^{3}$} \\
\hline Control & $83.44 \pm 2.16$ & $85.85 \pm 2.32$ & $85.14 \pm 3.24$ & $86.46 \pm 1.12$ \\
\hline $5,0 \mathrm{mg} / \mathrm{kg}$ & $81.23 \pm 3.12$ & $84.46 \pm 3.38$ & $85.26 \pm 1.35$ & $84.08 \pm 2.44$ \\
\hline $25,0 \mathrm{mg} / \mathrm{kg}$ & $78.64 \pm 2.47 *$ & $83.94 \pm 2.64$ & $84.11 \pm 2.53$ & $85.92 \pm 2.15$ \\
\hline $50,0 \mathrm{mg} / \mathrm{kg}$ & $77.27 \pm 1.34 *$ & $82.23 \pm 3.31$ & $83.85 \pm 2.62$ & $84.54 \pm 3.05$ \\
\hline \multicolumn{5}{|c|}{ Hematocrit (HCT), \% } \\
\hline Control & $31.15 \pm 1.28$ & $33.18 \pm 2.12$ & $31.08 \pm 0.90$ & $32.11 \pm 2.26$ \\
\hline $5,0 \mathrm{mg} / \mathrm{kg}$ & $32.24 \pm 2.08$ & $31.86 \pm 1.20$ & $33.10 \pm 0.72$ & $32.04 \pm 1.15$ \\
\hline $25,0 \mathrm{mg} / \mathrm{kg}$ & $36.18 \pm 2.22 *$ & $33.98 \pm 0.86$ & $30.95 \pm 1.35$ & $31.93 \pm 2.34$ \\
\hline $50,0 \mathrm{mg} / \mathrm{kg}$ & $38.21 \pm 1.18^{*}$ & $32.96 \pm 1.36$ & $33.02 \pm 2.08$ & $33.90 \pm 2.12$ \\
\hline \multicolumn{5}{|c|}{ Mean erythrocyte volume (MCV), $\mu^{3}$} \\
\hline Control & $121.98 \pm 3.90$ & $121.20 \pm 2.40$ & $123.88 \pm 1.94$ & $121.98 \pm 2.18$ \\
\hline $5,0 \mathrm{mg} / \mathrm{kg}$ & $122.12 \pm 1.72$ & $121.89 \pm 1.90$ & $122.20 \pm 4.93$ & $121.10 \pm 3.39$ \\
\hline $25,0 \mathrm{mg} / \mathrm{kg}$ & $121.94 \pm 2.19$ & $122.05 \pm 2.39$ & $122.12 \pm 2.99$ & $121.04 \pm 2.13$ \\
\hline $50,0 \mathrm{mg} / \mathrm{kg}$ & $123.02 \pm 1.07$ & $122.10 \pm 3.91$ & $123.02 \pm 1.80$ & $123.04 \pm 1.64$ \\
\hline \multicolumn{5}{|c|}{ Erythrocytes (RBC), 1012/dm ${ }^{3}$} \\
\hline Control & $4.71 \pm 0.20$ & $4.74 \pm 0.08$ & $4.71 \pm 0.11$ & $4.32 \pm 0.31$ \\
\hline $5,0 \mathrm{mg} / \mathrm{kg}$ & $4.36 \pm 0.25$ & $4.73 \pm 0.18$ & $4.52 \pm 0.16$ & $4.76 \pm 0.09$ \\
\hline $25,0 \mathrm{mg} / \mathrm{kg}$ & $4.64 \pm 0.18$ & $4.89 \pm 0.21$ & $4.61 \pm 0.06$ & $4.50 \pm 0.23$ \\
\hline $50,0 \mathrm{mg} / \mathrm{kg}$ & $3.16 \pm 0.28 *$ & $4.70 \pm 0.12$ & $4.58 \pm 0.31$ & $4.81 \pm 0.20$ \\
\hline
\end{tabular}

Analyzing the obtained data (Table 3), a statistically significant decrease in the concentration of total hemoglobin in the blood of broilers of group III and IV on day 7 of the experiment by 5.75 and $7.39 \%$, respectively. On the 14th and 28th day of the experiment, no probable changes in the indicators were registered.

On the 7th day of the experiment, a probable $(p<0.05)$ increase in hematocrit (ratio of the volume of formed blood elements to the total blood volume) in broiler chickens of groups III and IV (doses of 25.0 and $50.0 \mathrm{mg} / \mathrm{kg}$ ) by 16.15 and $22.66 \%$, respectively. On the 14th and 28th day of the experiment, no probable changes in hematocrit were registered. Analysis of the dynamics of erythrocyte indices showed that the value of the mean erythrocyte volume (MCV) did not differ significantly from the control values at all-time points. A probable decrease in the number of erythrocytes in broilers of group IV $(50.0 \mathrm{mg} / \mathrm{kg}$ ) on 7 day by $32.91 \%$ was found.

Thus, during the study of hematological parameters it was found that the receipt of the formulation with feed in the range of doses studied, causes a decrease in hemoglobin concentration and an increase in hematocrit in broiler chickens on day 7 of the experiment. It was found that the changes are reversible, on the 28th day of the experiment the value of these indicators was within the physiological norm. The results of the study of the functional state of the liver and kidneys of broiler chickens are shown in Table 4.
Assessing the dynamics of biochemical parameters of the serum of broiler chickens, it was found that the intake of the feed formulation of antiemeric drug based on maduramycin and nicarbazine in poultry for 28 days causes probable changes in the activity of nonliver enzymes ALT and AST for 7.0 days $\mathrm{mg} / \mathrm{kg}$ ) by 20.0 and $32.4 \%$, respectively. A probable increase in the concentration of total protein in the serum of broiler chickens of the IV experimental group by $9.34 \%$ was found. The concentration of albumin on day 7 of the experiment was significantly $(\mathrm{p}<0.05)$ higher than the control in broiler chickens of III and IV groups (doses of 25.0 and $50.0 \mathrm{mg} / \mathrm{kg}$ ) by 27.69 and $41.13 \%$, respectively. On days 14 and 28 , as well as 7 days after cessation of administration, the concentration of total protein and albumin was within the physiological norm.

According to the results of biochemical studies found a statistically significant $(p<0.05)$ increase in the concentration of creatinine in the serum of broiler chickens of group IV (dose $50.0 \mathrm{mg} / \mathrm{kg}$ ) on days 7 and 14 of the experiment by 5.34 and $3.31 \%$, respectively. At 28 days and 7 days after discontinuation of the formulation, no probable deviations of this indicator were registered. Assessing the dynamics of uric acid content, a probable increase in the blood serum of broiler chickens III and IV (doses of 25.0 and $50.0 \mathrm{mg} / \mathrm{kg}$ ) on the 7 th day of the experiment by 2.09 and $7.39 \%$, respectively. 
Table 4

Dynamics of the main biochemical parameters of blood serum of broiler chickens with subacute administration of a formulation based on maduramycin and nicarbazine $(M \pm m ; n=5)$

\begin{tabular}{|c|c|c|c|c|}
\hline \multirow[b]{2}{*}{ Groups } & \multicolumn{4}{|c|}{ Terms of research, days } \\
\hline & 7 & 14 & 28 & $\begin{array}{c}7 \text { after administra- } \\
\text { tion }\end{array}$ \\
\hline \multicolumn{5}{|c|}{ ALT, $\mu \mathrm{mol} / \mathrm{h} \times \mathrm{cm} 3$} \\
\hline Control & $0.35 \pm 0.04$ & $0.35 \pm 0.02$ & $0.36 \pm 0.08$ & $0.36 \pm 0.08$ \\
\hline $5,0 \mathrm{mg} / \mathrm{kg}$ & $0.33 \pm 0.05$ & $0.34 \pm 0.06$ & $0.35 \pm 0.04$ & $0.35 \pm 0.05$ \\
\hline $25,0 \mathrm{mg} / \mathrm{kg}$ & $0.36 \pm 0.04$ & $0.36 \pm 0.05$ & $0.37 \pm 0.02$ & $0.37 \pm 0.07$ \\
\hline $50,0 \mathrm{mg} / \mathrm{kg}$ & $0.42 \pm 0.04 *$ & $0.36 \pm 0.04$ & $0.36 \pm 0.05$ & $0.36 \pm 0.04$ \\
\hline \multicolumn{5}{|c|}{$\mathrm{AST}, \mu \mathrm{mol} / \mathrm{h} \times \mathrm{cm} 3$} \\
\hline Control & $4.51 \pm 0.24$ & $4.69 \pm 0.37$ & $4.65 \pm 0.25$ & $4.61 \pm 0.24$ \\
\hline $5,0 \mathrm{mg} / \mathrm{kg}$ & $4.45 \pm 0.35$ & $4.55 \pm 0.28$ & $4.65 \pm 0.38$ & $4.65 \pm 0.38$ \\
\hline $25,0 \mathrm{mg} / \mathrm{kg}$ & $4.45 \pm 0.29$ & $4.64 \pm 0.35$ & $4.65 \pm 0.35$ & $4.62 \pm 0.32$ \\
\hline $50,0 \mathrm{mg} / \mathrm{kg}$ & $5.97 \pm 0.34 *$ & $4.58 \pm 0.18$ & $4.64 \pm 0.24$ & $4.65 \pm 0.35$ \\
\hline \multicolumn{5}{|c|}{ Total protein, $\mathrm{g} / \mathrm{dm} 3$} \\
\hline Control & $47.55 \pm 1.72$ & $46.21 \pm 3.05$ & $46.14 \pm 1.08$ & $45.85 \pm 1.02$ \\
\hline $5,0 \mathrm{mg} / \mathrm{kg}$ & $46.91 \pm 2.70$ & $45.32 \pm 2.12$ & $45.09 \pm 3.21$ & $46.97 \pm 2.07$ \\
\hline $25,0 \mathrm{mg} / \mathrm{kg}$ & $45.11 \pm 1.23$ & $47.94 \pm 1.01$ & $46.85 \pm 2.05$ & $47.05 \pm 1.05$ \\
\hline $50,0 \mathrm{mg} / \mathrm{kg}$ & $51.99 \pm 1.56^{*}$ & $46.05 \pm 2.91$ & $46.94 \pm 2.09$ & $46.10 \pm 3.84$ \\
\hline \multicolumn{5}{|c|}{ Albumin, g/dm3 } \\
\hline Control & $26.72 \pm 2.25$ & $27.06 \pm 2.25$ & $27.01 \pm 3.05$ & $27.07 \pm 2.08$ \\
\hline $5,0 \mathrm{mg} / \mathrm{kg}$ & $26.68 \pm 1.095$ & $27.01 \pm 1.84$ & $27.05 \pm 1.05$ & $26.87 \pm 2.05$ \\
\hline $25,0 \mathrm{mg} / \mathrm{kg}$ & $34.12 \pm 3.03 *$ & $26.95 \pm 1.12$ & $27.08 \pm 2.06$ & $26.81 \pm 2.06$ \\
\hline $50,0 \mathrm{mg} / \mathrm{kg}$ & $37.71 \pm 1.05^{*}$ & $27.15 \pm 2.15$ & $26.99 \pm 2.05$ & $27.05 \pm 1.25$ \\
\hline \multicolumn{5}{|c|}{ Creatinine, $\mu \mathrm{mol} / \mathrm{dm} 3$} \\
\hline Control & $170.63 \pm 4.85$ & $171.48 \pm 2.05$ & $172.46 \pm 3.25$ & $172.12 \pm 12.05$ \\
\hline $5,0 \mathrm{mg} / \mathrm{kg}$ & $172.31 \pm 5.58$ & $169.95 \pm 2.24$ & $173.85 \pm 4.09$ & $173.31 \pm 10.25$ \\
\hline $25,0 \mathrm{mg} / \mathrm{kg}$ & $173.01 \pm 3.05$ & $173.01 \pm 3.15$ & $170.15 \pm 5.05$ & $170.98 \pm 20.05$ \\
\hline $50,0 \mathrm{mg} / \mathrm{kg}$ & $179.74 \pm 4.01 *$ & $177.16 \pm 4.04 *$ & $171.29 \pm 4.01$ & $172.17 \pm 17.09$ \\
\hline \multicolumn{5}{|c|}{ Uric acid, $\mu \mathrm{mol} / \mathrm{dm} 3$} \\
\hline Control & $325.18 \pm 7.15$ & $326.20 \pm 3.05$ & $327.24 \pm 8.08$ & $326.12 \pm 9.07$ \\
\hline $5,0 \mathrm{mg} / \mathrm{kg}$ & $324.32 \pm 5.05$ & $325.99 \pm 5.25$ & $326.15 \pm 9.01$ & $327.59 \pm 8.05$ \\
\hline $25,0 \mathrm{mg} / \mathrm{kg}$ & $331.98 \pm 9.55^{*}$ & $325.18 \pm 8.01$ & $325.89 \pm 7.27$ & $325.67 \pm 17.02$ \\
\hline $50,0 \mathrm{mg} / \mathrm{kg}$ & $349.20 \pm 8.07^{*}$ & $329.01 \pm 4.25$ & $328.12 \pm 8.54$ & $327.01 \pm 20.04$ \\
\hline
\end{tabular}

Note: $*-p<0.05 ; * *-p<0.01$ according to the indicator in the control

Thus, in the study of the functional state of the liver and kidneys, it was found that the intake of a formulation of antiemeric drug based on maduramycin and nicarbazine for 28 days does not adversely affect the body of broiler chickens under subacute experiment.

\section{Discussion}

Analyzing the results of studies conducted by other scientists [16], it was found that the effects of new combined drugs based on maduramycin and nicarbazine on the metabolism of broiler chickens remain poorly understood and require additional research.

The main focus was on determining the toxic effects of the formulation on the body of laboratory rats and broiler chickens under subacute experiment. Clinical and biochemical studies were performed. It should be noted that the determination of biochemical parameters is of diagnostic value for the prevention of acute and chronic poisoning of poultry. By changes in some biochemical parameters, it is possible to determine the target organs and doses of toxic substances that disrupt the metabolism of animals and birds in the absence of specific clinical signs of poisoning. The study of hematological parame- ters is an important step in determining the effect of the formulation on the body of rats and birds [17].

Prerequisite for timely diagnosis and treatment of animals is early enzyme diagnosis. The study of the activity of enzymes in the serum (plasma) is becoming increasingly important in determining the development of the pathological process, because the change in their activity occurs faster than other indicators [18]. Of particular interest to us was the determination of changes in the level of activity of certain enzymes that occur in the body under conditions of subacute oral administration of the drug mixture in selected doses, because intoxication clinical signs are sometimes absent or weak and the negative effect of the drug can be judged only by some biochemical indicators. Studies of enzymatic activity began with the determination of the activity of AST and ALT, as these enzymes are one of the main indicators of toxic liver damage [19].

In a subacute experiment, in order to study the mechanisms of toxic effects of the formulation based on maduramycin and nicarbazine on the body of white rats and broiler chickens, we conducted a study of a number of informative physiological, hematological and bio- 
chemical parameters. The analysis of the obtained results showed that long-term intake of the formulation in doses of 25 and $50 \mathrm{mg} / \mathrm{kg}$ of feed to the bird did not cause clinical signs of poisoning, but caused the development of hematotoxic effects and changes in the functional state of liver and kidneys of experimental animals on day 7 of the experiment. However, the results of our research show that such changes were reversible and disappeared in other terms of the study.

Study limitations. The obtained results cannot fully characterize all toxicological features of a complex antiemeric agent based on maduramycin and nicarbazine under the conditions of a single intragastric adminis-tration.

Prospects for further research. In the future, we plan to conduct studies of carcinogenicity and dermal toxicity of the antiemetic formulation based on maduramycin and nicarbazine in laboratory animals.

\section{Conclusions}

1. During the study of the general clinical condition of rats and chickens of the experimental groups, no significant changes in behavior and appearance were detected, compared with the control.
2. In the study of hematological and biochemical parameters it was found that the receipt of the formulation based on maduramycin and nicarbazine with food in doses of 25.0 and $50.0 \mathrm{mg} / \mathrm{kg}$ for 28 days, causes a decrease in hemoglobin and increase hematocrit, total protein concentration, albumin, creatinine and urea in male rats on day 7 of the experiment.

3. In the study of the functional state of the liver and kidneys, it was found that the intake of the formulation of antiemeric drug based on maduramycin and nicarbazine for 28 days does not adversely affect the body of broiler chickens under subacute experiment.

\section{Conflict of interests}

The authors declare that they have no conflicts of interest.

\section{Financing}

The study was performed without financial support.

\section{Acknowledgment}

The authors thank the staff of the toxicological monitoring laboratory.

\section{References}

1. Castanon, J. I. R. (2007). History of the Use of Antibiotic as Growth Promoters in European Poultry Feeds. Poultry Science, 86 (11), 2466-2471. doi: http://doi.org/10.3382/ps.2007-00249

2. Chapman, H. D. (2018). Applied strategies for the control of coccidiosis in poultry. CAB Reviews: Perspectives in Agriculture, Veterinary Science, Nutrition and Natural Resources, 13 (26). doi: http://doi.org/10.1079/pavsnnr201813026

3. Rybicki, M. J. (2020) Coccidiostats in treating coccidiosis. ŻYWNOŚĆ. Nauka. Technologia. Jakość, 27 (4 (125)), 127-137.

4. Joachim, A., Altreuther, G., Bangoura, B., Charles, S., Daugschies, A., Hinney, B. et. al. (2018). WAAVP guideline for evaluating the efficacy of anticoccidials in mammals (pigs, dogs, cattle, sheep). Veterinary Parasitology, 253, 102-119. doi: http://doi.org/10.1016/j.vetpar.2018.02.029

5. Noack, S., Chapman, H. D., Selzer, P. M. (2019). Anticoccidial drugs of the livestock industry. Parasitology Research, 118 (7), 2009-2026. doi: http://doi.org/10.1007/s00436-019-06343-5

6. Dorne, J. L. C. M., Fernández-Cruz, M. L., Bertelsen, U., Renshaw, D. W., Peltonen, K., Anadon, A. et. al. (2013). Risk assessment of coccidostatics during feed cross-contamination: Animal and human health aspects. Toxicology and Applied Pharmacology, 270 (3), 196-208. doi: http://doi.org/10.1016/j.taap.2010.12.014

7. National Center for Biotechnology Information (2021). PubChem Compound Summary for CID 196129, Maduramicin. Available at: https://pubchem.ncbi.nlm.nih.gov/compound/Maduramicin

8. Rumbeiha, W. K., Snider, D. B. (2014). Veterinary Toxicology. Encyclopedia of Toxicology. Academic Press, 915-928. doi: http://doi.org/10.1016/b978-0-12-386454-3.00444-9

9. Arisov, M. V., Urazaev, D. N., Kachanova, E. O., Pavlova, A. S. (2020). General principles of conducting preclinical toxicology studies of antiparasitic drugs for veterinary use. IOP Conference Series: Earth and Environmental Science, 548, 042042. doi: http://doi.org/10.1088/1755-1315/548/4/042042

10. Kociumbas, I. Ja. (2005). Doklinichni doslidzhennja veterinarnih likarskih zasobiv. Lviv: Triada pljus, 134-147.

11. Dotsenko, R., Vashchyk, Y., Zakhariev, A., Zemlianskyi, A., Dotsenko, E., Seliukova, N. (2021). Determination of toxicological characteristics of a complex antiemeric drug based on maduramycin and nicarbazine. ScienceRise: Biological Science, 2 (27), 37-43. doi: http://doi.org/10.15587/2519-8025.2021.235941

12. OECD (2008). Test No. 407: Repeated Dose 28-day Oral Toxicity Study in Rodents, OECD Guidelines for the Testing of Chemicals, Section 4. OECD Publishing. Paris. doi: http://doi.org/10.1787/9789264070684-en

13. Kaneko, J. J., Harvey, J. W., Bruss, M. L. (Eds.) (1997). Clinical Biochemistry of Domestic Animals. San Diego: Academy Press. doi: http://doi.org/10.1016/b978-0-12-396305-5.x5000-3

14. Prozorovski, V. B. (2007). Statisticheskaja obrabotka rezultatov farmakologicheskih issledovanii. Psikhofarmakologiia i biologicheskaia narkologiia, 3-4, 2090-2120.

15. Pro zakhyst tvaryn vid zhorstokoho povodzhennia (2006): Zakon Ukraini No. 3447-IV. 21.02.2006. Available at: http://zakon5.rada.gov.ua/laws/show/3447-15

16. Filazi, A., Yurdakok-Dikmen, B.; Gupta, R., Srivastava, A., Lall, R. (Eds.) (2019). Regulatory Guidelines for Nutraceuticals and Dietary Supplements for Animals in Turkey. Nutraceuticals in Veterinary Medicine. Cham: Springer, 829-236. doi: http://doi.org/10.1007/978-3-030-04624-8_62

17. Durai, P., Maruthai, T., Arumugam, S., Venugopal, O. (2012). Haematological profile and erythrocyte indices in different breeds of poultry. International Journal of Livestock Research, 2 (3), 89. doi: http://doi.org/10.5455/ijlr.20120824083537

18. Wang, X., Su, S., Ihsan, A., Huang, Q., Chen, D., Cheng, G. et. al. (2015). Acute and sub-chronic toxicity study of diaveridine in Wistar rats. Regulatory Toxicology and Pharmacology, 73 (1), 232-240. doi: http://doi.org/10.1016/ j.yrtph.2015.07.010 
19. Michael D. Willard, Harold Tvedten. Small Animal Clinical Diagnosis by Laboratory Methods (Fourth Edition). 2004, ISBN 9780721689036, https://doi.org/10.1016/B0-72-168903-5/50005-7

Received date 10.08.2021

Accepted date 16.09.2021

Published date 30.09.2021

Roman Dotsenko, PhD, Senior Researcher, Associate Professor, Department of Veterinary Medicine and Pharmacy, National University of Pharmacy, Pushkinska str., 53, Kharkiv, Ukraine, 61002

Maryna Romanko, Doctor of Biological Sciences, Leading Researcher, Laboratory for Toxicological Monitoring, National scientific center «Institute of Experimental and Clinical Veterinary Medicine», Pushkinska str., 83, Kharkiv, Ukraine, 61023

Yevheniia Vashchyk, Doctor of Veterinary Sciences, Associate Professor, Department of Veterinary Medicine and Pharmacy, National University of Pharmacy, Pushkinska str., 53, Kharkiv, Ukraine, 61002

Andriy Zakhariev, PhD, Associate Professor, Department of Veterinary Medicine and Pharmacy, National University of Pharmacy, Pushkinska str., 53, Kharkiv, Ukraine, 61002

Andrii Zemlianskyi, PhD, Assistant, Department of Veterinary Medicine and Pharmacy, National University of Pharmacy, Pushkinska str., 53, Kharkiv, Ukraine, 61002

Ekaterina Dotsenko, PhD, Senior Researcher, Laboratory "Veterinary sanitation and parasitology", National scientific center «Institute of Experimental and Clinical Veterinary Medicine», Pushkinska str., 83, Kharkiv, Ukraine, 61023

Nataliia Seliukova, Doctor of Biological Sciences, Associate Professor, Department of Veterinary Medicine and Pharmacy, National University of Pharmacy, Pushkinska str., 53, Kharkiv, Ukraine, 61002

*Corresponding author: Roman Dotsenko,e-mail: romdtox@ukr.net 